\title{
Understanding Australian Income Inequality: The Proper Role played by Globalisation, De-unionisation and the Terms of Trade
}

\author{
Noel Gaston ${ }^{1}$
}

\begin{abstract}
This paper examines the key determinants of Australia's income inequality. The main finding is that 'globalisation' — broadly-defined - has increased income inequality. However, this impact is not attributable to increased trade openness and falling trade barriers.
\end{abstract}

\section{Income inequality and the presumed role of globalisation}

While the recent increases in income inequality are well-documented, considerable controversy still exists over which factors have been the most important causes of this trend. ${ }^{2}$ However, one of the essential claims in the popular writing on globalisation is its supposed impact on inequality. The role played by globalisation on labour market outcomes and income inequality in developed countries has been a particularly fertile ground for research during a time when international trade liberalisation has progressed and concerns about imports from low-skill-abundant, less-developed countries (LDCs) have been prominent. $^{3}$

At the outset, it should be noted that increased earnings dispersion in the developed economies does not appear to have been primarily the result of shifts in employment from manufacturing to services. Even for the countries that witnessed the greatest increases in earnings dispersion, the increased-earnings dispersion phenomenon has been observed within narrowly-defined industries

\footnotetext{
1 Globalisation and Development Centre and School of Business, Bond University, Gold Coast, Queensland 4229, Australia. Correspondence: ngaston@bond.edu.au. This paper is partly drawn from a paper (co-authored with Gulasekaran Rajaguru) delivered at a recent conference as well as a forthcoming book on measuring globalisation (co-authored with Axel Dreher and Pim Martens). Comments provided by the editor, William Coleman, as well as two anonymous referees were very helpful. The editor, referees and my various co-authors are absolved of any responsibility for my errors and opinions.

2 As Borland (1999) notes, very little is known about the determinants of the increases in Australian inequality experienced in the last two decades of the last millennium.

3 Some early studies, using a variety of methodologies, found significant labour market effects attributable to increasing import penetration. Borjas and Ramey (1994) found that U.S. earnings inequality (from 1963 to 1988) and the durable goods trade deficit are co-integrated; that is, they have the same long-run trend. Also, Wood (1994) argues that freer trade with LDCs adversely affects low-wage workers in developed economies. As we note in the next section, these 'negative' findings are relatively uncommon in the more recent literature.
} 
across the entire economy. On the face of things, the latter observation seems to rule out the more hasty of the trade-related explanations. Trade economists have long argued that the natural framework for thinking about the long-run effect of trade on labour markets, at least from a maintained assumption of competitive markets, is the Stolper-Samuelson theorem and its various generalisations. ${ }^{4}$ Simply stated, the implication of the theorem for skilled-labour-abundant developed economies is that a reduction in the relative price of unskilled-labour-intensive goods caused by more liberal trade with LDCs will lower the relative return to unskilled labour in the developed economies. The simplest trade model predicts that increased trade with countries like China and India would worsen the distribution of earnings in developed countries.

The trade-theoretic account of trade shocks as running from commodity-price changes to factor-price changes provides a compelling equilibrium mechanism and some useful rough empirical checks. Nevertheless, the aggregate professional consensus would seem to have settled on the conclusion that trade has a relatively small effect on the skill-premium, but that other factors (especially skill-biased technological change) are more important. Consistent with this consensus, Gaston (1998) finds that the declines in Australian manufacturing employment were barely affected by lower levels of trade protection. ${ }^{5}$ Gaston also finds that Australian real earnings were extremely resilient in view of the (then) most recent recession and trade liberalisation. In addition, he finds that the adverse employment developments were, at most, weakly linked to this real wage resistance. ${ }^{6}$

Compounding the problems of inference, it is extremely difficult to unravel the distinct impacts of technical change and international trade on labour market outcomes. For example, globalisation may lower the costs of diffusing new technology and encourage capital for labour as well as skilled for unskilled labour substitution. More speculatively, the rate of technical progress may be an endogenous response to the need to maintain competitiveness in the global marketplace. The same type of argument can also be made about increasing global competition and institutional changes, such as de-unionisation and the decentralisation of wage bargaining, which are both features of many developed economies, including Australia.

\footnotetext{
4 The surveys of this literature are now almost sufficiently numerous to warrant a survey of their own. Slaughter (2000) is a good survey of work explicitly rooted in the Stolper-Samuelson theorem.

${ }^{5}$ While the estimates are generally small (that is, a less than one per cent reduction in employment for each 10 per cent reduction in the effective rate of industry assistance), the effect approximately doubled in the time period after the program of general tariff reductions implemented in 1988.

${ }^{6}$ Gaston's findings were confirmed using more disaggregated data and different empirical techniques by Murtough et al. (1998). Borland (1999) reaches a similar conclusion.
} 
Furthermore, since countries with similar standards of living and economic development generally have access to labour and capital of similar quality, it is quite likely that the magnitude and nature of any technical changes will also be similar. In fact, it has been argued that this must also be true for any changes on the demand-side, since European Union countries were also affected by import penetration from countries abundant in unskilled labour (Katz et al., 1995). Given this similarity in aggregate endowment, technology and shocks, it seems quite natural to investigate the institutional forces operating in each country to explain cross-country differences in the trends and structure of earnings dispersion. In the United Kingdom and the United States, de-unionisation has been a significant labour market development, in economies in which structures are already relatively decentralised (Katz, 1993). Naturally, these changes are not independent of growing international competition. During the 1990s, Australia implemented a number of labour market reforms to decentralise its traditionally centralised form of wage bargaining. The argument made by employer groups has been that such changes were inevitable because of the need to maintain international competitiveness (Borland, 1999).

Overall, the widespread concern with globalisation may have emerged as a result of changes that are obscured when standard economics methods are used to study the labour market effects of globalisation. The primary focus of the existing literature has been on the direct effects of globalisation - the direct effects of the flows of goods and factors of production on labour markets - and on not the indirect effects of globalisation. ${ }^{7}$ But indirect effects also operate on the labour market, by transforming the structures that support one set of equilibria and inducing change in those equilibria. Because economic and political structures are related, changes in the relationship of a national economy to the global economy can produce profound changes in the political-economic arrangements of a country. In addition to affecting equilibrium wages and employment, such changes could well be unsettling in themselves.

The altered roles of labour unions and the welfare state provide obvious examples of the importance of institutional differences. Part of the support for relatively unskilled workers' incomes comes from the mutually supporting institutions of unions and welfare state. That is, as a result of labour market institutions, such as labour unions, some workers receive a higher wage than other otherwise identical workers. A common finding is that measures of wage centralisation are generally negatively associated with wage dispersion (for example, Blau and Kahn, 1996). Likewise, higher rates of unionisation and collective bargaining tend to be associated with a lower incidence of low-paid

\footnotetext{
7 See Gaston and Nelson (2004).
} 
employment and less earnings inequality. ${ }^{8}$ In fact, the increases in inequality in recent years have coincided with more decentralised wage bargaining and de-unionisation.

It should be clear that globalisation could affect the union bargaining strength and workers' incentive to unionise, with straightforward implications for equilibrium relative wages. There is now a sizable body of research examining the relationship between the institutional structure of the unionised sector of an economy (that is, the extent and centralisation of organisation) and various measures of macroeconomic performance. Countries with encompassing labour market institutions (that is, large unionised sectors with centralised bargaining) are characterised by: lower wage inequality (Rowthorn, 1992; OECD, 1997); lower unemployment (OECD, 1997); and higher growth (Rowthorn, 1992; Calmfors, 1993). The usual explanation involves the ability of centralised bargaining institutions to internalise negative wage externalities (Calmfors, 1993). That is, where strong sectoral unions pursue wage gains relative to some perceived market wage, resulting in cost-push inflation, reduced employment, lower growth and inter-sectoral inequality, the centralised union recognises these negative externalities and takes them into account in its bargaining. Thus, as unionisation has declined, there is some evidence that wage inequality has increased (Freeman, 1998). ${ }^{9}$

Increased inequality, and real deterioration in the labour market outcomes of unskilled workers, is also directly related to changes in demand for welfare-state provision. For example, it has been observed that despite increases in the dispersion of earned incomes that, in some countries at least, inequality in post-transfer and post-tax income inequality has not grown (Gottschalk and Smeeding, 1997). This suggests that political pressures have been brought to bear on the generosity of public transfers at a time when earned incomes have become more unequally distributed. From a political-economic perspective, the growing inequality of income could be associated with strong compositional effects on the demand for public insurance. In particular, it seems to be the case that the growing size and economic significance of sectors of the economy that pay higher wages for certain types of workers, could result in political pressures that lead to higher levels of transfer payments to disadvantaged workers. This

8 DiNardo and Lemieux (1997) conclude that the greater de-unionisation of the workforce in the United States relative to Canada can explain much of the difference in male earnings inequality between the two countries.

9 The membership of unions fell in most OECD countries in the 1980s. An associated trend in many of these countries is varying degrees of decentralisation in wage bargaining institutions since the beginning of the 1980s. According to Wallerstein and Western (2000), two crucial longitudinal features of union organisation and the centralisation of wage setting are as follows. First, labour market regulation, unionisation and bargaining centralisation in industrialised countries steadily diverged over the three decades from 1950. Second, there was a convergent pattern of decline in union density and centralised wage setting during the 1980s. Falling unionisation was especially severe in the English-speaking countries (Wallerstein and Western, 2000, pp.357-8). 
could result from changes in the identity of the median voter or as an optimal response to increased income risk in an increasingly open economy (Alesina and Rodrik, 1994).

Some scholars argue that the increased mobility of capital not only erodes the tax base, reducing the state's ability to fund welfare programs, but by shifting taxes onto labour, the capacity of the state to redistribute is reduced (Tanzi, 1995). For example, some European countries, in the face of increased international competition, have tried to reduce the 'generosity' of their social programs (Gaston and Nelson, 2004 and Gaston and Rajaguru, 2007a). In ways that are harder to quantify, but seem prima facie plausible, the decreasing cost of the exit option increases the relative power of business in policy-making (Huber and Stephens, 1998). Finally, it has been argued that globalisation increases the general credibility of orthodox (that is, market-oriented) policy advice, thus reducing the plausibility of arguments supporting welfare state expansion and enhancing the credibility of arguments in favour of welfare-state retrenchment (Krugman, 1999). In the popular consciousness, at least, coincident with the recent onset of globalisation has been a move towards privatisation, deregulation, neo-liberalism and 'economic rationalism'. In the case of Australia, John Quiggin (1999, p.240) argues that 'Increased inequality is the result of the neoliberal reform program as a whole. The role of globalisation per se has been overstated.'

Finally, it is being increasingly recognised that globalisation has important social and political dimensions in addition to the usual economic dimensions of primary interest to economists. For example, recent research finds that social integration contributed to de-unionisation in OECD countries, while economic globalisation mattered far less (Dreher and Gaston, 2007a). Although largely neglected in the economics literature, both political integration and social integration are likely to be important for income inequality. For example, in the absence of restrictions on capital mobility, a country is more likely to competitively lower taxes or offer subsidies to attract investment, the closer a potential host country's culture is to that of a source country and the easier it is to exchange information. Lower taxes may also lower social standards and this is one channel through which the social dimension of globalisation may be important for income inequality. On the other hand, political integration may ameliorate a potential 'race to the bottom' which may be induced by economic globalisation. Hence, while economic globalisation may increase inequality, political globalisation could actually serve to reduce it.

In the debate about the consequences of globalisation it is important not to take an overly narrow perspective of globalisation as this may severely bias conclusions about the 'true' effects, direct and indirect, on labour markets and income inequality. In addition to the more standard supply-and-demand factors, 
inequality may be adversely affected by changes in labour market institutions, trade liberalising policies (often bundled with privatisation and deregulation measures as well as changes to social policies; see Lindert and Williamson, 1991) and a variety of non-economic factors which have simultaneously affected many economies. $^{10}$

\section{Some data on Australian income inequality and globalisation}

\section{Some Measures of Inequality.}

Figure 1 plots income-inequality data computed by Leigh (2005) using Australian taxation statistics for the period 1970 to $2001 .^{11}$

Figure 1: Inequality Among Adult Males in Australia, 1970-2001

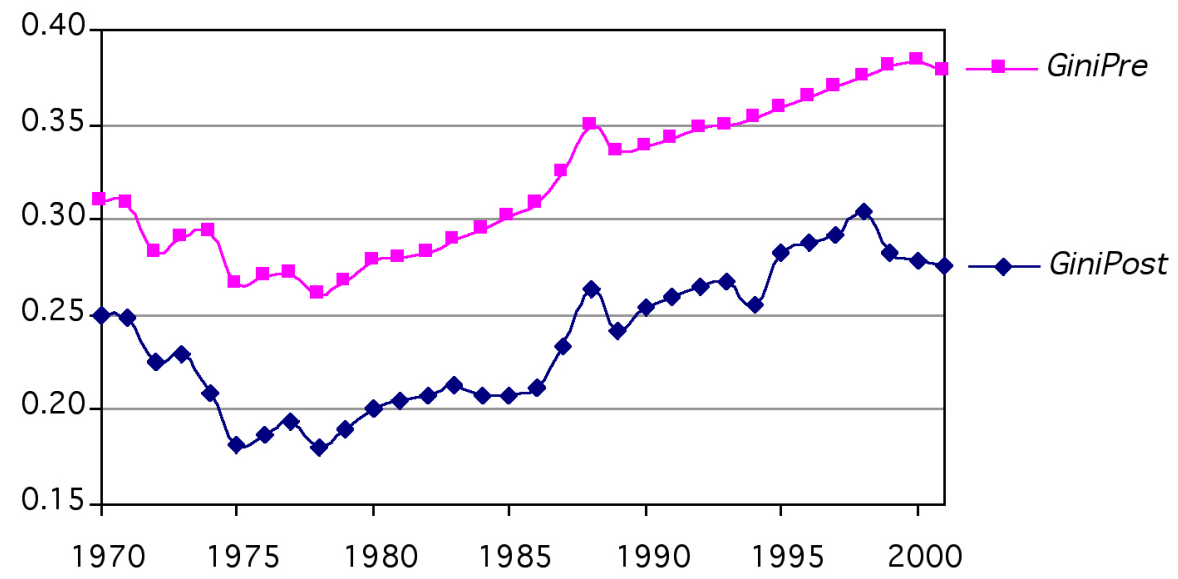

This paper focuses on three measures - GiniPre is the Gini coefficient for pre-tax income, GiniPost is the Gini coefficient for post-tax income, and P9050 is the ratio of the income of an individual at the ninetieth percentile divided by the income of an individual at the fiftieth percentile. ${ }^{12}$ The reason for using both of the first two measures is to distinguish the impact of the progressivity of the taxation system in possibly neutralising the effects of globalisation. The third measure focuses on the issue of whether individuals at the top of the income

10 Globalisation is sometimes equated with 'Americanisation'. For example, see Friedman (1999).

11 The inequality data are from Leigh's Table 1: Inequality Among Male Adults in Australia for the years 1970-2001. Leigh imputes the incomes of non-taxpayers and derives the underlying distribution of income. Leigh shows that the distribution of adult male incomes and the distribution of family incomes are highly correlated for the United States and argues that the same is likely to be true for Australia. Borland (1999) shows that female employees had higher increases in real weekly earnings compared to males. Additionally, while changes in above-median earnings dispersion for males and females are quite similar, male employees had a higher increase in below-median earnings dispersion than female employees.

${ }^{12}$ The Gini coefficient ranges from 0 (perfect equality) to 1 (perfect inequality). 
distribution have fared particularly well during the latest wave of globalisation (as argued by Atkinson, 2003, for example).

Notwithstanding their differences, the three measures are highly correlated. Observe that all three measures increased over the 32-year time span — with pre-tax income inequality rising by almost 22 per cent.

\section{A Measure of Globalisation}

To assess the extent to which any country is more (or less) globalised at any particular point requires much more than employing data on flows of trade, migration or FDI. When a phenomenon like globalisation encompasses several aspects that, taken together, may have an effect greater than the sum of their constituent parts, it appears logical to assess these effects together. Composite indices provide an excellent way to accomplish this since they provide a single statistic on which comparisons can be based, without the confounding effects of variation at lower levels of aggregation.

The KOF index (Dreher et al., 2007) fits the bill; here it is simply labelled 'KOF'. The index is derived from 25 variables grouped into six 'sub-indices': actual flows of trade and investment; restrictions; variables measuring the degree of political integration; data quantifying the extent of personal contact with people living in foreign countries; data measuring trans-border flows of information; and a proxy for cultural integration.

The sub-index on actual economic flows includes data on trade, FDI and portfolio investment. Trade is measured as the sum of a country's exports and imports and portfolio investment is the sum of a country's assets and liabilities (all standardised by GDP). The KOF index includes the sum of gross inflows and outflows of FDI and the stocks of FDI (again, both standardised by GDP). While these variables are standard measures of globalisation, income payments to foreign nationals and capital are included to proxy the extent to which a country employs foreign labour and capital in its production processes.

The second sub-index includes restrictions on trade and capital using hidden import barriers, mean tariff rates, taxes on international trade (as a share of current revenue) and an index of capital controls. Given a certain level of trade, a country with higher revenues from tariffs is less globalised. To proxy restrictions on the capital account, data on 13 different types of capital controls are used.

The KOF has a sub-index on 'political globalisation', drawn from the number of embassies and high commissions in each country, the number of international organisations in which a country has membership and the number of United Nations peace missions participated in. 
The remaining three sub-indices of the KOF index concern 'social' globalisation; one on 'personal contacts', another on 'information flows', and a final one on 'cultural proximity'. The index on personal contacts includes international telecom traffic and the extent of tourism. Government and workers' transfers received (and paid) measures the extent to which countries interact, while the stock of foreign population is included to capture existing interactions with people from other countries. Finally, the average cost of a phone call to the United States measures the cost of international interaction.

While personal contact data are meant to capture interactions among people from different countries, the sub-index on 'information flows' measures the potential flow of ideas and images. It includes the number of internet hosts and users, telephone mainlines, cable television subscribers, the number of radios and sales of daily newspapers. 'Cultural proximity' is arguably the dimension of globalisation most difficult to grasp. One indicator is the number of McDonald's restaurants located in a country. For many people, the global reach of McDonald's is symbolic of globalisation itself.

These dimensions are then combined into an overall index of globalisation with an objective statistical method. ${ }^{13}$ Table 1 reports the weights of the individual components. ${ }^{14}$ As can be seen, economic, political and social integration obtained roughly equal weights. Table 1 shows that globalisation has increased dramatically.

\section{A Measure of Unionisation and the Terms of Trade}

The 'terms of trade' (ToT) is measured in this paper as the ratio of the implicit price deflator of exports of goods and services to the implicit price deflator of imports of goods and services. ${ }^{15}$ In the case of Australia, rising terms of trade are predicted to result in a movement of labour and capital from manufacturing to primary industries. Depending on these structural changes and any impediments to labour mobility, this could adversely affect the distribution of

13 Dreher et al. (2007) describe the method in more detail. The annual data are publicly available at: http://globalization.kof.ethz.ch/static/rawdata/globalization_2007_short.xls.

14 To construct the indices of globalisation, each variable (in Table 1) is converted into an index with a zero to 10 scale. Higher values denote greater globalisation. When higher values of the original variable indicate greater globalisation, the formula $\left((\mathrm{Vi}-\mathrm{Vmin}) /(\mathrm{Vmax}-\mathrm{Vmin})^{\star} 10\right)$ is used for transformation. Conversely, when higher values indicate less globalisation, the formula is ((Vmax $\left.\mathrm{Vi}) /(\mathrm{Vmax}-\mathrm{Vmin})^{*} 10\right)$. The weights for the sub-indices are calculated using principal components analysis. The base year is 2000. For this year, the analysis partitions the variance of the variables used. The weights are then determined in a way that maximises the variation of the resulting principal component, so that the index captures the variation as fully as possible. If possible, the weights determined for the base year are then used to calculate the indices for each single year back to 1970. Where no data are available, the weights are re-adjusted. See Dreher et al. (2007) for further details of the computational method.

15 The terms of trade data are from the Reserve Bank of Australia (which, in turn, are derived from ABS Cat No 5206.0). The implicit price deflators are indexed with a reference year 2004/05 = 100 . Available at: http://www.rba.gov.au/Statistics/Bulletin/G04hist.xls. 
earnings via a straightforward interpretation of the Stolper-Samuelson theorem (Henry, 2006). All other data are from the OECD. ${ }^{16}$

\section{Table 1: Components of the KOF index of globalisation}

\begin{tabular}{|c|c|c|c|}
\hline & Indices and Variables & & Weights \\
\hline \multirow[t]{12}{*}{ A. } & Economic Globalisation & & {$[36 \%]$} \\
\hline & i) Actual Flows & & $(50 \%)$ \\
\hline & & Trade (per cent of GDP) & $16 \%$ \\
\hline & & FDI, flows (per cent of GDP) & $21 \%$ \\
\hline & & FDI, stocks (per cent of GDP) & $23 \%$ \\
\hline & & Portfolio investment (per cent of GDP) & $19 \%$ \\
\hline & & $\begin{array}{l}\text { Income payments to foreign nationals (per } \\
\text { cent of GDP) }\end{array}$ & $22 \%$ \\
\hline & ii) Restrictions & & $(50 \%)$ \\
\hline & & Hidden import barriers & $24 \%$ \\
\hline & & Mean tariff rate & $28 \%$ \\
\hline & & $\begin{array}{l}\text { Taxes on international trade (per cent of } \\
\text { current revenue) }\end{array}$ & $28 \%$ \\
\hline & & Capital account restrictions & $20 \%$ \\
\hline \multirow[t]{17}{*}{ B. } & Social Globalisation & & [38\%] \\
\hline & i) Data on Personal Contact & & $(29 \%)$ \\
\hline & & Outgoing telephone traffic & $14 \%$ \\
\hline & & Transfers (per cent of GDP) & $8 \%$ \\
\hline & & International tourism & $27 \%$ \\
\hline & & $\begin{array}{l}\text { Foreign population (per cent of total } \\
\text { population) }\end{array}$ & $25 \%$ \\
\hline & & International letters (per capita) & $27 \%$ \\
\hline & ii) Data on Information Flows & & $(35 \%)$ \\
\hline & & Internet hosts (per 1000 people) & $20 \%$ \\
\hline & & Internet users (per 1000 people) & $24 \%$ \\
\hline & & Cable television (per 1000 people) & $20 \%$ \\
\hline & & Trade in newspapers (per cent of GDP) & $14 \%$ \\
\hline & & Radios (per 1000 people) & $23 \%$ \\
\hline & iii) Data on Cultural Proximity & & $(37 \%)$ \\
\hline & & $\begin{array}{l}\text { Number of McDonald's restaurants (per } \\
\text { capita) }\end{array}$ & $40 \%$ \\
\hline & & Number of Ikea outlets (per capita) & $40 \%$ \\
\hline & & Trade in books (per cent of GDP) & $20 \%$ \\
\hline \multirow[t]{4}{*}{ C. } & Political Globalisation & & {$[26 \%]$} \\
\hline & & Embassies in country & $35 \%$ \\
\hline & & Membership in international organisations & $36 \%$ \\
\hline & & $\begin{array}{l}\text { Participation in U.N. Security Council } \\
\text { missions }\end{array}$ & $29 \%$ \\
\hline
\end{tabular}

'Union' is union membership standardised by the total labour force (that is, expressed as a percentage). As discussed in the previous section, the usual

16 The OECD data are from: http://stats.oecd.org/wbos/default.aspx. 
prediction is that de-unionisation worsens earnings and income inequality. From Table 2 below, note that the rate of unionisation fell by an astounding 42 per cent. The minimum wage is converted to real terms using the CPI. This measure is included to capture the response of the welfare state to increased global uncertainty. Interestingly, this measure rose strongly over the latter part of the 32-year period. ${ }^{17}$ On the face of things, this rise is consistent with the argument made by Rodrik (1998) discussed in the previous section. Finally, 'Open' is the usual openness measure; that is, the ratio of total trade (imports plus exports) divided by GDP. It displays extraordinary growth from 1970 to 2001. It is included separately from the broad index of globalisation to focus on growing economic integration in particular. ${ }^{18}$ Based on previous research, small effects on the income distribution are anticipated.

Table 2 and Figure 2 present several dimensions of the data used in our econometric analysis.

\section{Table 2: Descriptive Statistics}

\begin{tabular}{|c|c|c|c|c|c|c|c|c|c|c|c|}
\hline & \multirow[b]{2}{*}{ Mean } & \multirow[b]{2}{*}{ Min. } & \multirow[b]{2}{*}{ Max. } & \multirow{2}{*}{$\begin{array}{c}\text { Change } \\
1970-2001\end{array}$} & \multicolumn{7}{|c|}{ Correlations } \\
\hline & & & & & 1) & 2) & 3) & 4) & 5) & 6) & 7) \\
\hline 1) GiniPost & 0.32 & 0.26 & 0.38 & $21.9 \%$ & & & & & & & \\
\hline 2) GiniPre & 0.24 & 0.18 & 0.30 & $10.0 \%$ & 0.95 & & & & & & \\
\hline 3) p9050 & 1.88 & 1.70 & 2.09 & $16.1 \%$ & 0.94 & 0.97 & & & & & \\
\hline 4) KOF & 65.1 & 47.2 & 80.9 & $71.5 \%$ & 0.78 & 0.90 & 0.92 & & & & \\
\hline 5) ToT & 83.1 & 71.7 & 106.5 & $-11.4 \%$ & -0.36 & -0.46 & -0.47 & -0.61 & & & \\
\hline 6) Open & 33.2 & 25.4 & 44.8 & $61.0 \%$ & 0.70 & 0.84 & 0.85 & 0.93 & -0.57 & & \\
\hline 7) Union & 34.2 & 21.4 & 40.1 & $-42.1 \%$ & -0.84 & -0.89 & -0.90 & -0.86 & 0.44 & -0.91 & \\
\hline 8) $R M W$ & 276.23 & 221.21 & 310.01 & $27.7 \%$ & 0.41 & 0.46 & 0.51 & 0.54 & -0.16 & 0.58 & -0.57 \\
\hline
\end{tabular}

The decline of union membership during the 1990s is quite stark. The real minimum wage (converted to an index in the figure) displays fluctuations, but is considerably higher at the end of the period compared to the beginning. In contrast, ToT is lower in 2001 compared to 1970 (and predates the most recent minerals-driven increases in the terms of trade). Both trade openness and KOF trend sharply upwards over the entire period.

\section{Time Series Analysis}

The formal statistical analysis of each of the inequality measures (KOF, ToT, Open, Union and $L R M W$ ) indicates that they are co-integrated with one co-integrating vector. This suggests estimation of a vector error-correction model

\footnotetext{
17 The annual percentage rise in the real minimum wage is actually quite small when considering the effects of compounding and productivity growth in the Australian economy. However, two related points are noteworthy here. First, in 2000 the Australian minimum wage was the second highest in the OECD (Martin and Immervoll, 2007). Secondly, all labour market bargaining models predict that the wages for non-minimum-wage workers are anchored by minimum wages.

18 From Table 1 note that this customary measure of trade openness receives just a 5.76 per cent (that is, $0.36 \times 0.16$ ) weight in the overall KOF globalisation index.
} 
to establish the relationship between the variables ${ }^{19}$ All the standardised beta coefficients for the long-run relationships are summarised in Table 3.

Figure 2: Time Series of Covariates, 1970-2001

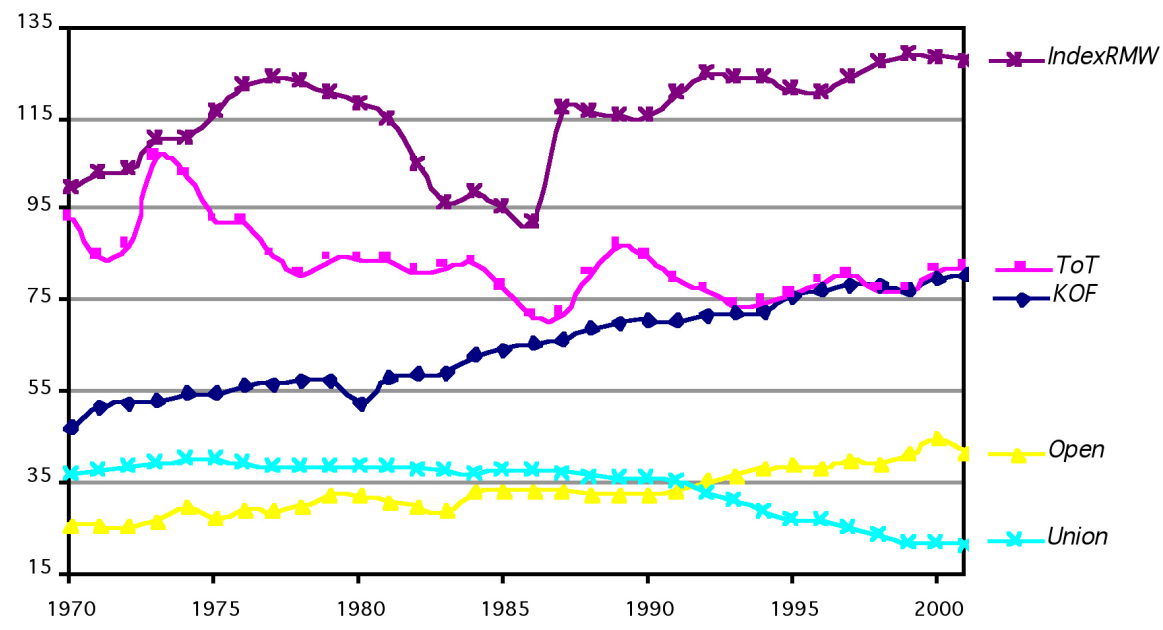

Table 3: Summary of the long-run relationships: standardised beta coefficients

\begin{tabular}{|l|r|r|r|r|r|}
\hline & KOF & ToT & OPEN & \multicolumn{1}{l|}{ Union } & \multicolumn{1}{c|}{ LRMW } \\
\hline GiniPre & $0.52^{* * *}$ & $-0.51^{* * *}$ & 0.00 & $-0.39^{* * *}$ & $-0.36^{* * *}$ \\
\hline GiniPost & $0.81^{* *}$ & $-1.76^{* * *}$ & $-3.42^{* * *}$ & $-2.48^{* * *}$ & $0.26^{*}$ \\
\hline p9050 & $1.24^{* * *}$ & $-0.59^{* * *}$ & $-3.34^{* * *}$ & $-4.57^{* * *}$ & 0.03 \\
\hline
\end{tabular}

Note: ${ }^{*}{ }^{* *}$ and ${ }^{* * *}$ denote rejection of the null at 10 per cent, 5 per cent and 1 per cent significance levels, respectively.

The results of Table 3 indicate that globalisation, as measured by $K O F$, unambiguously increases income inequality. (A one standard deviation increase in $K O F$ leads to 0.52 standard deviation increase in GiniPre (pre-tax income inequality), ceteris paribus. ${ }^{20}$ This is in line with the findings of Dreher and Gaston (2007b), who found that globalisation increases income inequality in a panel of OECD countries. $^{21}$ The finding mirrors the unease with which non-economists and the public generally view globalisation. While the academic

19 The optimal lag length of two is determined by the Schwartz criteria. Even though there are just 32 annual observations the long-run relationship in the error correction model uses five degrees of freedom and each short-run equation uses eight degrees of freedom. For technical and estimation details, see Gaston and Rajaguru (2007b).

${ }^{20}$ It should be noted that although there is one co-integrating relationship, the causal interpretation is subjective. For example, it was also found that GiniPre, KOF, Union and LRMW affect ToT.

$2 \mathrm{I}$ Exploring the Dreher and Gaston (2007b) result in greater depth, Dreher et al. (2007) found that it is the social dimension of globalisation that has had the most significant impact on OECD earnings and income inequality. 
literature fails to find consistent evidence that traditional measures of economic openness and integration - such as international trade flows and immigration - adversely impact the labour market, this may be attributable to an overly narrow view of globalisation generally adopted by most economists. ${ }^{22}$

Perhaps a more surprising result of Table 3 is that improving terms of trade and greater trade openness are equity-enhancing for Australia. Of course, Australia is somewhat 'peculiar' for a developed economy in that it mainly exports primary commodities and imports manufactured goods. Pope and Selten (2002) have noted the importance of improved terms of trade for Australia's manufacturing sector. Perhaps for this reason, not only do improved terms of trade boost Australian welfare and income, they also have a beneficial impact on equity.

The results for 'Union' are large and significantly negative as well as straightforward to interpret. It's quite clear that de-unionisation has exacerbated income inequality. The result for the minimum wage varies across the different measures of income inequality. A higher real minimum wage lowers pre-tax income inequality. The impact on post-tax inequality is positive and significant, albeit at just the 10 per cent level. This may indicate that the progressivity of taxes is relatively more important for generating a more equitable income distribution than are increases in the minimum wage, at least for Australia. Unsurprisingly, the minimum wage has no impact on the income distribution for the more wealthy.

\section{Conclusion}

This paper examined the key determinants of Australia's income inequality. Surprisingly, particularly given the increases in Australian income inequality over the last quarter-century, little research has been done for Australia. The present paper can therefore be viewed as a preliminary exploration. The findings are intriguing and will hopefully encourage other researchers to further explore the issue. Among the findings is that more trade and improved terms of trade are equity-enhancing. Institutionally, de-unionisation of the labour force is having the anticipated adverse effect on income inequality. On the other hand, the welfare state has responded; rising minimum wages - the anchor upon which low-skilled and semi-skilled workers have their own incomes determined - have reduced income inequality. In addition, the progressivity of the income tax system has served to lessen the impact on low-income workers. The main finding is that globalisation — broadly-defined - has increased income inequality. Notably, the result is not attributable to increased trade openness and falling trade barriers. In fact, quite the opposite is the case. The global

\footnotetext{
22 The co-integration analysis revealed that KOF is likely to be exogenous (that is, it is highly significant in the three long-run relationships but insignificant in each of the speed of adjustment equations). This contradicts the view by Quiggin (1999) quoted above. On the other hand, the conclusions drawn by Henry and O’Brien (2003) do seem overly sanguine.
} 
environment, and Australia's role in that environment, is a starkly different and possibly more uncertain one than Australians found ourselves in a quarter-century ago.

\section{References}

Alesina, A., and D. Rodrik 1994, 'Distributive politics and economic growth', Quarterly Journal of Economics 109(2), pp.465-90.

Atkinson, A. B. 2003, 'Income inequality in OECD countries: data and explanations', CESifo Economic Studies 49(4), pp.479-513.

Blau, F. D., and L. M. Kahn 1996, 'International differences in male wage inequality: institutions versus market forces', Journal of Political Economy 104(4), pp.791-837.

Borjas, G. J., and V. A. Ramey 1994, 'Time-series evidence and the sources of trends in wage inequality', American Economic Review 84(2), pp.10-6.

Borland, J. 1999, 'Earnings inequality in Australia: changes, causes and consequences', Economic Record 75(299), pp.177-202.

Calmfors, L. 1993, 'Centralisation of wage bargaining and macroeconomic performance - a survey', OECD Economic Studies 21, pp.161-91.

DiNardo, J., and T. Lemieux 1997, 'Diverging male wage inequality in the United States and Canada, 1981-1988: do institutions explain the difference?', Industrial and Labor Relations Review 50(4), pp.629-51.

Dreher, A., and N. Gaston 2007a, 'Has globalisation really had no effect on unions?', Kyklos 60(2), pp.165-86.

_ 2007b, 'Does globalisation increase inequality?', Review of International Economics, forthcoming. and P. Martens 2007, Measuring Globalisation, Berlin: Springer-Verlag, forthcoming.

Freeman, R. B. 1998, 'War of the models: which labour market institutions for the $21^{\text {st }}$ century?' Labour Economics 5(1), pp.1-24.

Friedman, T. L. 1999, The Lexus and the Olive Tree, New York: Farrar, Strauss and Giroux.

Gaston, N. 1998, 'The impact of international trade and protection on Australian manufacturing employment', Australian Economic Papers 37(2), pp.119-36.

and G. Rajaguru 2007a, 'The rise (and fall) of labour market programmes: domestic vs. global factors', Oxford Economic Papers, forthcoming. 
2007b, 'Has globalisation increased Australian inequality?', paper delivered at the Conference on the Australian and Japanese Labour Markets Compared, held at ANU on 6 July 2007.

and D. Nelson 2004, 'Structural change and the labour market effects of globalisation', Review of International Economics 12(5), pp.769-92.

Gottschalk, P., and T. M. Smeeding 1997, 'Cross-national comparisons of earnings and income inequality', Journal of Economic Literature 35(2), pp.633-87.

Henry, K. 2006, 'Implications of China's re-emergence for Australia', address to Australian Business Economists, 16 May 2006.

and T. O'Brien 2003, ‘Globalisation, poverty and inequality: friends, foes or strangers?', Australian Economic Review 36(1), pp.3-21.

Huber, E., and J. Stephens 1998, 'Internationalization and the social democratic model', Comparative Political Studies 31(3), pp.353-97.

Katz, H. C. 1993, 'The decentralization of collective bargaining: a literature review and comparative analysis', Industrial and Labor Relations Review 47(1), pp.3-22.

Katz, L. F., G. W. Loveman and D. G. Blanchflower 1995, 'A comparison of changes in the structure of wages in four OECD countries', in R. B. Freeman and L. F. Katz, editors, Differences and Changes in Wage Structures, Chicago: University of Chicago Press, pp.25-66.

Krugman, P. 1999, 'Domestic policies in a global economy', Brookings Trade Forum - 1999, Washington, DC: Brookings, pp.73-93.

Leigh, A. 2005, 'Deriving long-run inequality series from tax data', Economic Record 81(255), S58-S70.

Lindert, P. H., and J. G. Williamson 2001, 'Does globalization make the world more unequal?' NBER working paper no.8228.

Martin, J., and H. Immervoll 2007, 'The minimum wage: making it pay', OECD Observer, no.261, pp.11-2.

Murtough, G., K. Pearson and P. Wreford 1998, 'Trade liberalisation and earnings distribution in Australia', Industry Commission Staff Research Paper, Canberra: AGPS.

Organisation for Economic Co-operation and Development (OECD) 1997, Employment Outlook, OECD, Paris.

Pope, R., and R. Selten 2002, 'Local manufacturing hurt by depreciations in a theoretical model reflecting the Australian experience', Pacific Economic Review 7(3), pp.403-64. 
Quiggin, J. 1999, 'Globalisation, neoliberalism and inequality in Australia', Economic and Labour Relations Review 10(2), pp.240-59.

Rodrik, D. 1997, Has Globalisation Gone Too Far? Washington, DC: Institute for International Economics.

1998, 'Why do more open economies have bigger governments?' Journal of Political Economy 106(5), pp.997-1032.

Rowthorn, R. E. 1992, 'Centralisation, employment and wage dispersion', Economic Journal 102 (412), pp.506-23.

Slaughter, M. 2000, 'What are the results of product-price studies and what can we learn from their differences?', in R. Feenstra, editor, The Impact of International Trade on Wages, Chicago: University of Chicago Press, pp.129-65.

Tanzi, V. 1995, Taxation in an Integrating World, Washington, DC: Brookings Institution.

Wallerstein, M., and B. Western 2000, 'Unions in decline: what has changed and why?', Annual Review of Political Science 3(3), pp.355-77.

Wood, A. 1994, North-South Trade, Employment and Inequality: Changing Fortunes in a Skill-Driven World, New York: Oxford University Press. 